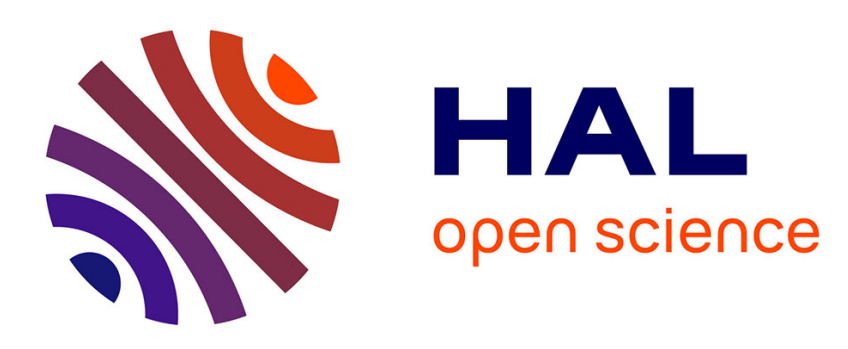

\title{
Tritylium assisted iodine catalysis for the synthesis of unsymmetrical triarylmethanes
}

Thibaut Courant, Marine Lombard, Dina Boyarskaya, Luc Neuville, Geraldine Masson

\section{- To cite this version:}

Thibaut Courant, Marine Lombard, Dina Boyarskaya, Luc Neuville, Geraldine Masson. Tritylium assisted iodine catalysis for the synthesis of unsymmetrical triarylmethanes. Organic \& Biomolecular Chemistry, 2020, 18 (33), pp.6502-6508. 10.1039/D0OB01502D . hal-03009611

\section{HAL Id: hal-03009611 \\ https://hal.science/hal-03009611}

Submitted on 24 Nov 2020

HAL is a multi-disciplinary open access archive for the deposit and dissemination of scientific research documents, whether they are published or not. The documents may come from teaching and research institutions in France or abroad, or from public or private research centers.
L'archive ouverte pluridisciplinaire HAL, est destinée au dépôt et à la diffusion de documents scientifiques de niveau recherche, publiés ou non, émanant des établissements d'enseignement et de recherche français ou étrangers, des laboratoires publics ou privés. 


\section{Tritylium assisted iodine catalysis for the synthesis of unsym- metrical triarylmethanes}

Received 00th January 20xx,

Thibaut Courant, Marine Lombard, Dina V. Boyarskaya, Luc Neuville, Géraldine Masson*

Accepted 00th January 20xx

DOI: $10.1039 / \times 0 \times x 00000 x$

The combined Lewis acid catalytic system, generated from molecular iodine and tritylium tetrafluoroborate effectively catalyzed the Friedel-Crafts (FC) arylation of diarylmethyl sulfides providing an efficient access to various unsymmetrical triarylmethanes. The addition of tritylium and iodine created a more active catalytic system to promote the cleavage of sulfidic C$S$ bonds.

Unsymmetrical triarylmethanes ${ }^{1}$ represent an important class of organic molecules due to their occurrence in bioactive natural products (such as muchimangin G-J, ${ }^{1 f}$ melanervin $^{1 \mathrm{k}}$ ) and pharmaceuticals ${ }^{1 g-i}$ (Figure 1).<smiles>[R]c1c([R])c([R])c2c(=O)c3c(O)c(C(c4ccccc4)c4cc(OC)c(OC)cc4OC)c(O)c(OC)c3oc2c1[R]</smiles>

muchimangin $\mathrm{G}: \mathrm{R}^{1}=\mathrm{R}^{2}=\mathrm{R}^{3}=\mathrm{OMe}, \mathrm{R}^{4}=\mathrm{H}$ muchimangin $H: R^{1}=H, R^{2}=R^{3}=R^{4}=O M e$ muchimangin $\mathrm{I}: \mathrm{R}^{1}=\mathrm{R}^{3}=\mathrm{OMe}, \mathrm{H}, \mathrm{R}^{2}=\mathrm{R}^{4}=\mathrm{H}$ muchimangin $G: R^{1}=R^{4}=O M e, R^{2}=R^{3}=-C_{2}-$

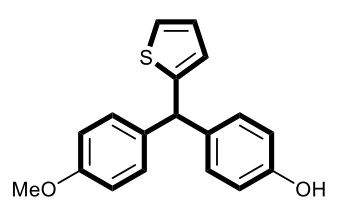

antitubercular agent

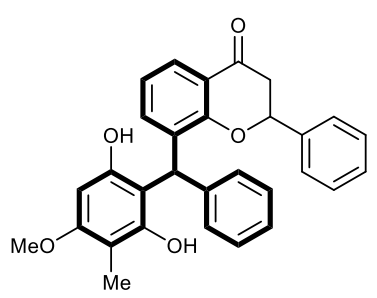

melanervin

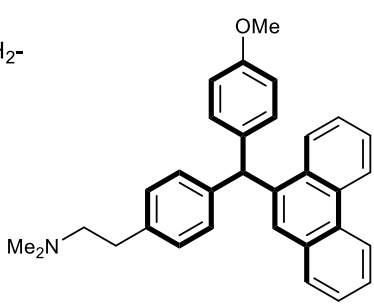

anti-breast cancer agent
Figure 1 Representative examples containing triarylated methanes.

a. Institut de Chimie des Substances Naturelles CNRS, Univ. Paris-Saclay, 1 Avenue de la Terrasse, 91198 Gif-sur-Yvette Cedex, France E-mail: Geraldine.masson@cnrs.fr.

† Footnotes relating to the title and/or authors should appear here.

Electronic Supplementary Information (ESI) available: [details of any supplementary information available should be included here]. See DOI: 10.1039/x0xx00000x
Moreover, the molecules containing a triarylmethane motif exhibit interesting photophysical properties and have also found numerous applications mainly in dyes, fluorescent probes and optoelectronic devices. ${ }^{1 a, e}$ Accordingly, a number of efforts have been conducted to develop efficient catalytic methods for their preparation. The most frequently employed approach relies on Friedel-Crafts (FC) arylation of unsymmetrical diarylmethanol, diarylmethyl ethers, diarylmethyl sulfones, diarylmethyl sulfonamides, diarylmethyl carbamates or diarylmethyl phosphates in the presence of Brønsted or Lewis acids (A, Scheme 1). ${ }^{2,3}$ Although this traditional method is straightforward and convergent, it suffers from limitations such as harsh reaction conditions that include high acidity and/or temperature. In this regard, we have recently disclosed an efficient visible-light photoredox catalyzed FC reaction of readily accessible diarylmethyl benzylsulfides ${ }^{4}$ leading to various triarylalkanes under mild condition ( $B$, Scheme 1). ${ }^{5-7}$ However, this photocatalyzed desulfitative arylation was severely restricted to electron-rich diarylmethyl benzylsulfides. Even the neutral diphenylmethyl alkylsulfides produce only trace of triarylated products ( $15 \%$ yield). The presence of at least one electron-donating group on one of aromatic rings of 1 was essential for the $\mathrm{C}-\mathrm{S}$ bonds cleavage reaction to occur. In this context, we became interested in developing an alternative catalytic approach that could overcome these limitations regarding C-S cleavage of electron neutral and electrondeficient diarylmethyl alkylsulfides.

Over the past decade, molecular iodine has emerged as a cheap and non-toxic catalyst in various metal-free organic transformations. ${ }^{2 q, 8}$ Among them, iodine-promoted functionalization of sulfinic C-S bonds is an efficient method for constructing $\mathrm{C}-\mathrm{C}$ and $\mathrm{C}$-heteroatom bonds. For instance, iodine has been widely used for the anomeric activation of thioglycosides. ${ }^{9}$ In 2014, our group has developed iodoniumcatalyzed chemoselective C-S bond cleavage of $\alpha$ carbamoylsulfides to generate an $N$-acyliminium ion intermediates which can undergo addition of various nucleophiles to form $\alpha, \alpha$-disubstituted amines. ${ }^{71}$ In light of this 
work, we wondered whether iodine could be an effective catalyst to perform the desulfitative arylation of diarylmethyl sulfides. Herein, we report an efficient process for the synthesis of various triarylmethanes based on a catalyst combination of iodine and trityl salt. Noteworthy, the presence of electron donating group is not required and weakly electron withdrawing are tolerated on diarylmethyl sulfides, broadening the applicability of the $\mathrm{FC}$ reaction (C, Scheme 1 ).
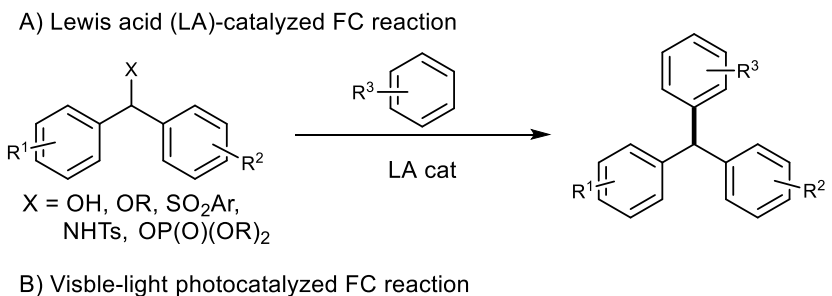

B) Visble-light photocatalyzed FC reaction
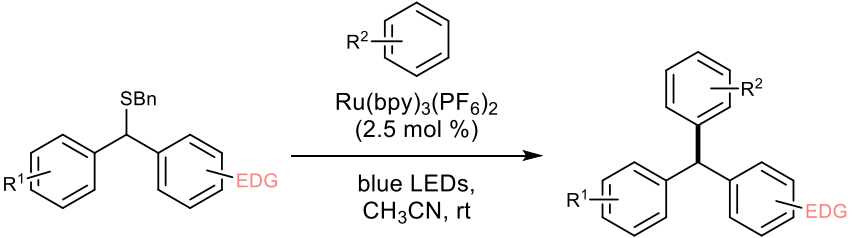

C) Our work: $I_{2}$-catalyzed $\mathrm{FC}$ reaction<smiles>[R]c1ccc(C([R17])c2ccc([R1])cc2)cc1</smiles>

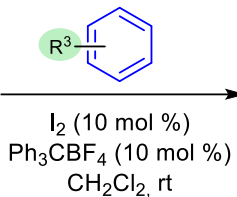<smiles>[R1]c1ccc(C(c2ccccc2)c2ccc([R2])cc2)cc1</smiles>

Scheme 1 Syntheses of triarylmethanes via FC-reaction.

To test the feasibility of this hypothesis, we carried out the FC reaction of 1-benzylthio(methylene)dibenzene (1aa) with 1,3,5trimethoxybenzene (2a) in the presence of $I_{2}$ in dichloromethane at room temperature (Table 1). As a result, the desired FC product 3a was formed in moderate yield $32 \%$ yield, Table 1 , entry 1 ). Modification of the catalyst loading did not really improve the result due to partial iodination of $2 \mathbf{a}$. The use of a base (such as $\mathrm{Na}_{2} \mathrm{HPO}_{4}$ or $\mathrm{Na}_{2} \mathrm{CO}_{3}$ ) in order to accelerate the rearomatization step did not lead to any improvement of the reaction (entries 3-4). In an attempt to improve the catalytic efficiency, we then turned our attention to the concept of combined Lewis acids introduced by Yamamoto. ${ }^{10,11}$ Addition of a Lewis acid may enhance the Lewis acid character of $I_{2}$ and thus favoring the overall process. ${ }^{9 g}, \mathrm{~h}$ To our delight, a significant improvement was found when the reaction was conducted in the presence of $10 \mathrm{~mol} \%$ of tritylium tetrafluoroborate and gave the desired product in $87 \%$ yield (entry 5 )..$^{12}$ Decreasing the amount of $I_{2}$ as well as $4 c$ led to a diminished yield (entries 6-9). The use of other solvents such as acetonitrile, and toluene resulted in slightly lower yields (entries 10-11). When i-PrOH was used as solvent, the undesired O-alkylated product was formed as major product (entry 12). It was observed that the nature of the substituent on the $S$ atom played an important role in the present transformation. No reaction occurred when sterically hindered S-trityl 1ae was used (entry 16). In sharp contrast, S-phenyl (1ab, entry 13) and S-ethyl (1ac, entry 14) derivatives gave similar results, with $87 \%$ yield of $3 a$. Slightly better yields were observed with the S-tert-butyl (1ad, entry 15). Further studies revealed that the Lewis acidity of triaryl salt affected significantly the yield, with $4 \mathrm{c}$ being optimal. When $I_{2}$ along with cyclic salts $\mathbf{4} \mathbf{f}$ and $\mathbf{4 g}$ were employed as a dual catalyst, 3a was isolated in lower yield (entries 19 and 20). Electron rich salts either reduced the yield of $\mathbf{3 a}$ or completely inhibited the reaction (entries 17 and 18).

Table 1 Optimization of reaction conditions

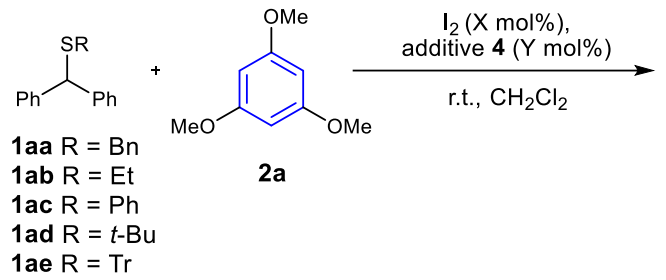<smiles>COc1cc(OC)c(C(c2ccccc2)c2ccccc2)c(OC)c1</smiles>

\begin{tabular}{|c|c|c|c|c|c|}
\hline Entry & 1 & $\mathrm{x}$ & Additive & $\mathrm{Y}$ & $\begin{array}{l}\text { Yield } \\
(\%)^{b}\end{array}$ \\
\hline $1^{\text {a }}$ & $1 \mathbf{a a}$ & 10 & - & - & 32 \\
\hline $2^{\mathrm{a}}$ & 1aa & 100 & - & - & 51 \\
\hline $3^{a, c}$ & 1aa & 10 & $\mathrm{Na}_{2} \mathrm{HPO}_{4}(4 a)$ & 10 & 16 \\
\hline $4^{a, c}$ & 1aa & 10 & $\mathrm{Na}_{2} \mathrm{CO}_{3}(\mathbf{4 b})$ & 10 & 34 \\
\hline $5^{d}$ & 1aa & 10 & $\mathrm{Ph}_{3} \mathrm{CBF}_{4}(4 \mathrm{c})$ & 10 & 87 \\
\hline $6^{d}$ & 1aa & 5 & $4 c$ & 5 & 59 \\
\hline $7^{\mathrm{d}}$ & 1 aa & 10 & $4 c$ & 7.5 & 65 \\
\hline $8^{d}$ & $1 \mathbf{a a}$ & 10 & $4 c$ & 5 & 58 \\
\hline $9^{d}$ & 1aa & 10 & $4 c$ & 2.5 & 35 \\
\hline $10^{\mathrm{d}, \mathrm{e}}$ & 1aa & 10 & $4 c$ & 10 & 78 \\
\hline $11^{\mathrm{d}, \mathrm{f}}$ & 1aa & 10 & $4 c$ & 10 & 75 \\
\hline $12^{\mathrm{d}, \mathrm{g}}$ & 1aa & 10 & $4 c$ & 10 & 18 \\
\hline $13^{d}$ & $1 a b$ & 10 & 4c & 10 & 87 \\
\hline $14^{\mathrm{d}}$ & $1 \mathrm{ac}$ & 10 & 4c & 10 & 87 \\
\hline $15^{\mathrm{d}}$ & 1ad & 10 & 4c & 10 & 91 \\
\hline $16^{d}$ & 1ae & 10 & 4c & 10 & 0 \\
\hline $17^{\mathrm{d}}$ & 1 ac & 10 & $\mathrm{p}-\mathrm{MeOC}_{6} \mathrm{H}_{4} \mathrm{Ph}_{2} \mathrm{CBF}_{4}(\mathbf{4 d})$ & 10 & $<10$ \\
\hline $18^{d}$ & $1 \mathrm{ac}$ & 10 & $\left(\mathrm{p}-\mathrm{MeOC}_{6} \mathrm{H}_{4}\right)_{3} \mathrm{CBF}_{4}(4 \mathrm{e})$ & 10 & 0 \\
\hline $19^{d}$ & $1 \mathrm{ac}$ & 10 & & 10 & 9 \\
\hline $20^{d}$ & $1 \mathrm{ac}$ & 10 & & 10 & 55 \\
\hline
\end{tabular}

${ }^{a}$ Reaction conditions: $1(0.1 \mathrm{mmol})$ and 1,3,5-trimethoxybenzene $2 \mathrm{a}(0.15 \mathrm{mmol}), \mathrm{I}_{2}(\mathrm{XX}$ $0.01 \mathrm{mmol}$ ) in $1 \mathrm{~mL}$ of $\mathrm{CH}_{2} \mathrm{Cl}_{2}$ at r.t. for 24 hours. ${ }^{b}$ Isolated yield after column chromatography. ${ }^{c}$ With 1 equiv. of base. ${ }^{d}$ Reaction conditions: $1(0.1 \mathrm{mmol})$ and 1,3,5trimethoxybenzene $2 \mathrm{a}(0.15 \mathrm{mmol}), \mathrm{I}_{2}(\mathrm{X} \times 0.01 \mathrm{mmol})$ and additive $(\mathrm{Y} \times 0.01 \mathrm{mmol})$ in 1 $\mathrm{mL}$ of $\mathrm{CH}_{2} \mathrm{Cl}_{2}$ at r.t. for 24 hours. ${ }^{e}$ Reaction in $\mathrm{CH}_{3} \mathrm{CN}$. ${ }^{f}$ Reaction in toluene. ${ }^{g}$ Reaction in isopropanol. 
With the optimized conditions set, the substrate scope of this FC reaction was investigated. A range of diarylmethyl sulfides was tested with 1,3,5-trimethoxybenzene (2a). Diarylmethanes with electron-withdrawing substituents (such as $\mathrm{F}, \mathrm{Cl}$, and $\mathrm{Br}$ ) at the para-position of the benzene ring gave the desired triarylmethanes $\mathbf{3 b - 3 d}$ in excellent yields. Remarkably, this catalytic system proved to be efficient for diarylmethanes bearing substituents at the meta position (such as F, 3e or OMe, 3f), which were totally unreactive in our previous photocatalyzed protocol. ${ }^{5 a}$ A lower yield $\mathbf{3 g}$ was obtained in the case of ortho-substituted sulfide, most likely due to unfavorable steric factors. We also found that, contrary to our previous studies, $^{5 a}$ substrate combining an electron rich arene with electron poor one participated smoothly in this reaction. For instance, the presence of $\mathrm{F}, \mathrm{Cl}, \mathrm{Br}$ and $\mathrm{CF}_{3}$ substituents at the meta- and para position led to the formation of triarylmethane products $\mathbf{3 h - 3 l}$ and $\mathbf{3 n}-\mathbf{3 s}$ in excellent yields. The reaction with diarylmethyl sulfides bearing only a CF3 group gave only trace of product. However, we were pleased to find that when the reaction was carried out with 1 equiv of $I_{2}$, the desired product $3 \mathrm{~m}$ was isolated in $33 \%$ yield. A sterically more demanding 1naphthyl group afforded the desired product $3 \mathbf{t}$ in $89 \%$ yield. The presence of heteroaromatic group such as thiophene was also compatible, providing an efficient access to antitubercular agents. ${ }^{1 \mathrm{~g}}$ Then, other electron-rich arenes $\mathbf{2}$ were evaluated. 1,2,3-Trimetoxybenzene underwent nucleophilic addition to 1ad affording $3 v$ in $64 \%$ yield. To our satisfaction, this condition was also applicable to the less-electron-rich arenes. For instance, 2-methylanisole and 1,2-dimethoxybenzene successfully produced the corresponding triarylmethane $\mathbf{3 w}$ and $\mathbf{3 x}$ in descent yield. 1,4-Dimethoxybenzene was also a competent reaction partner requiring nevertheless to heat the reaction at $50{ }^{\circ} \mathrm{C}$ to get adduct $3 y$ in low but significant yields. 1,3-Dimethoxybenzene proved to be more reactive. However, depending on the structure of $\mathbf{1}$, the mono-arylation product or a mixture of mono- and bis-arylation products were formed. Selective monoarylated product 3aa was formed from orthosubstituted aryl tert-butyl sulfide, while a separable mixture of mono- and diarylated products $\mathbf{3} z$ and $\mathbf{3} \mathbf{z}^{\prime}$ was obtained from 1ad. Pleasingly, increasing the amount of 1ac to 3 equiv. resulted in the predominant formation of mono-arylated product $3 z$, isolated in $74 \%$ yield. Interestingly, clean double FC could also be achieved (Scheme 3 ). As such, when arene $\mathbf{2} \mathbf{b}$ was used as limiting reagent ( 0.4 equiv) and opposed to thioether 1ad under otherwise identical conditions, compound $\mathbf{3} \mathbf{z}^{\prime}$ was exclusively formed and could be isolated in $90 \%$ yields. Reaction with other less nucleophilic arenes such as anisole and toluene, even an excess failed to produce the corresponding triarylmethanes.

To our delight, the dithioacetals $\mathbf{5}$ were also competent reaction partners under the developed conditions allowing for double thioether displacement. Indeed, 2,2' (phenylmethylene)bis(1,3,5-trimethoxybenzene) 3ab was easily synthetized in $64 \%$ yield from phenylbis(ethythio)methane. ${ }^{13}$ However in this case, full conversion was only achieved by adding a second batch of combined catalyst $\left(I_{2}\right.$ and $4 c, 10 \mathrm{~mol} \%$, respectively) after 24 hours.
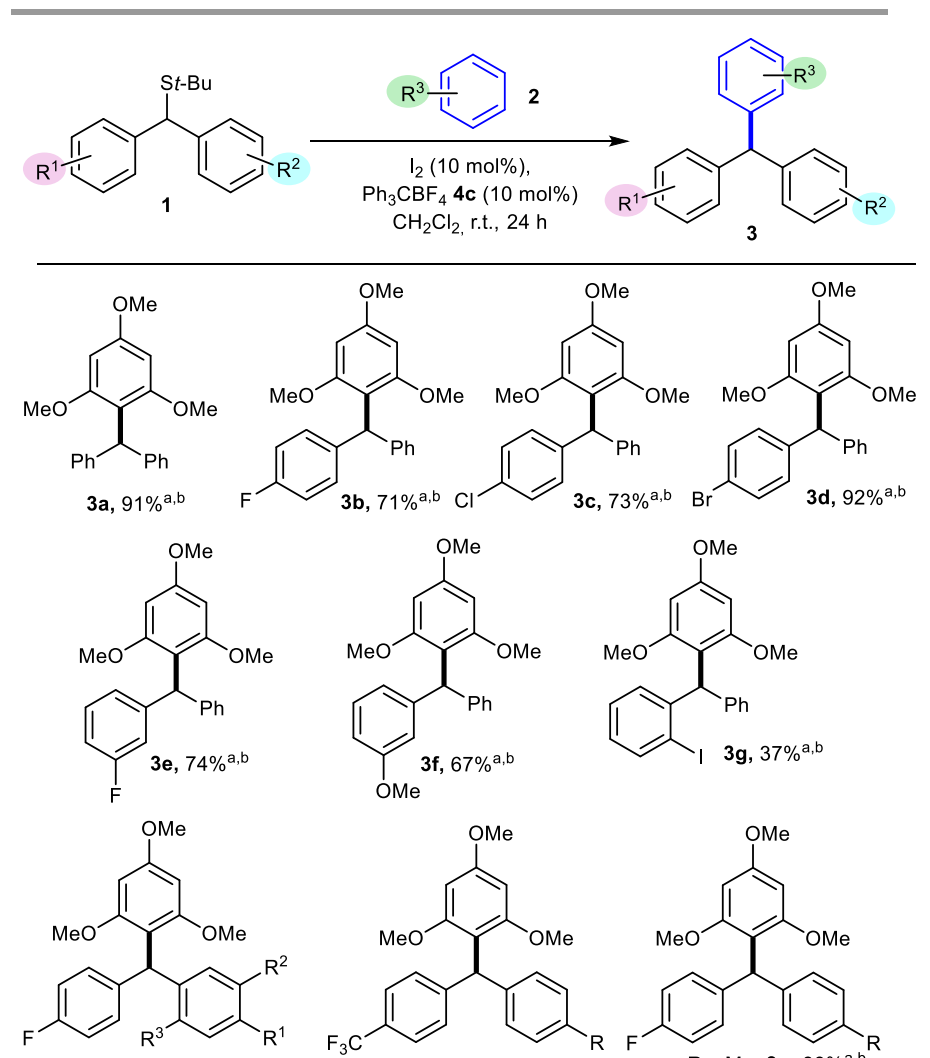

$\mathrm{R}^{1} / \mathrm{R}^{2} / \mathrm{R}^{3}=\mathrm{OMe} / \mathrm{H} / \mathrm{H}, \mathbf{3 h} 94 \% \%^{\mathrm{a}, \mathrm{b}}$ $\mathrm{R}^{1} / \mathrm{R}^{2} / \mathrm{R}^{3}=\mathrm{H} / \mathrm{OMe} / \mathrm{H}, \mathbf{3 i}, 86 \%{ }^{\mathrm{a}, \mathrm{b}}$ $\mathrm{R}^{1} / \mathrm{R}^{2} / \mathrm{R}^{3}=\mathrm{H} / \mathrm{H} / \mathrm{OMe}, 3 \mathrm{j}, 40 \%{ }^{\mathrm{a}, \mathrm{b}}$
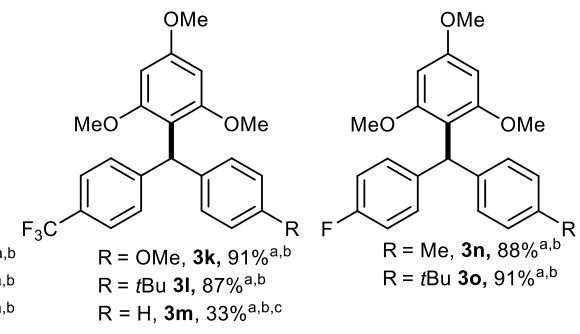<smiles>COc1ccc(C(c2cccc(F)c2)c2c(OC)cc(OC)cc2OC)cc1</smiles><smiles>[R]c1ccc(C(c2ccc([R])cc2)c2c(OC)cc(OC)cc2OC)cc1</smiles><smiles>COc1cc(OC)c(C(c2ccccc2)c2cccc3cc[14c](C)cc23)c(OC)c1</smiles><smiles>COc1cc(OC)c(C(c2ccc(Br)cc2)c2cccs2)c(OC)c1</smiles>
$\mathrm{R}^{1} / \mathrm{R}^{2}=\mathrm{Br} / \mathrm{i}-\operatorname{Pr} 3 \mathbf{s}, 92 \%^{\mathrm{a}, \mathrm{b}}$<smiles>[R]c1cc([R])c(C(c2ccccc2)c2ccccc2)cc1[R]</smiles>

$\mathrm{R}^{1} / \mathrm{R}^{2} / \mathrm{R}^{3}=\mathrm{Me} / \mathrm{OMe} / \mathrm{H}, 3 \mathrm{w}, 62 \% \mathrm{a}, \mathrm{b}$ $\mathrm{R}^{1} / \mathrm{R}^{2} / \mathrm{R}^{3}=\mathrm{OMe} / \mathrm{OMe} / \mathrm{H}, 3 \mathbf{3}, 40 \%^{\mathrm{a}, \mathrm{b}}(47 \%)^{\mathrm{a}, \mathrm{b}, \mathrm{e}}$ $\mathrm{R}^{1} / \mathrm{R}^{2} / \mathrm{R}^{3}=\mathrm{OMe} / \mathrm{H} / \mathrm{OMe}, 3$ y $35 \%^{\mathrm{a}, \mathrm{b}, \mathrm{e}}$<smiles>COc1ccc(C(c2ccccc2)c2ccccc2)c(OC)c1</smiles>

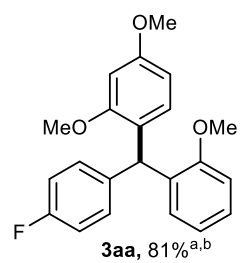

a Reaction conditions: 1 ( $0.1 \mathrm{mmol})$ and 1,3,5-trimethoxybenzene $2 \mathrm{a}(0.15 \mathrm{mmol}), \mathrm{I}_{2}$ (0.01 mmol) and $4 \mathrm{c}(0.01 \mathrm{mmol})$ in $1 \mathrm{~mL}$ of $\mathrm{CH}_{2} \mathrm{Cl}_{2}$ for 24 hours. ${ }^{b}$ Isolated yield after column chromatography. ${ }^{c}$ With 1 equiv of $\mathrm{I}_{2} \cdot{ }^{d}$ From 1 bearing $\mathrm{SBn} .{ }^{e}$ At $50{ }^{\circ} \mathrm{C}$. ${ }^{f}$ With 3 equiv of $\mathbf{2 b}$.

Scheme 2 Substrate Scope for the FC reaction of diarylmethyl sulfides 
<smiles>COc1ccc([C@H](c2ccccc2)C(c2ccccc2)c2ccccc2)c(OC)c1</smiles><smiles>CCC(C)c1ccccc1</smiles>
$(0.1 \mathrm{mmol}) \quad(0.4 \mathrm{mmol})$ $64 \%$

Scheme 3 Syntheses of triarylmethanes via double FC-reaction.

To gain an insight into the reaction mechanism, control experiments were performed. The use of $I_{2}$ catalyst appeared to be critical for the C-S bond cleavage reaction. Indeed, when the reaction was performed without $I_{2}$, there was no formation of the desired FC product, even if a stoichiometric amount of the trityl salt was added (A, Scheme 4). Thus, this result indicates that the Lewis acid carbocation only assists $I_{2}$ to promote the C$S$ bond cleavage. In addition, arylation of trityl benzylsulfide 6 did not proceed with $I_{2}$ catalyst or combined $I_{2} / 4 c$ catalysts ( $B$, Scheme 4).

A) Reaction without $\mathrm{I}_{2}$

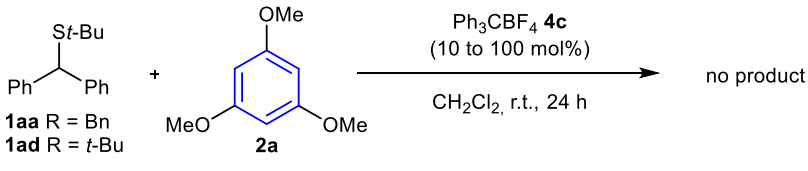

B) Reaction of triphenlymethyl sulfide

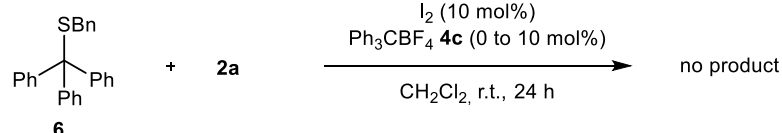

C) Reaction with Brønsted acid catalyst

$$
\text { 2a }
$$

Scheme 4 Control experiments.

On the basis of the results described above and previous works, $71,8,9$ two plausible mechanisms are proposed as outlined in Scheme 5. In absence of trityl cation, the sulfur atom of $\mathbf{1}$ is initially attacked by the iodine, leading to the formation of cationic iodosulfonium intermediate $\mathbf{7}$. Subsequently, the salt 7 undergoes an elimination to form the sulfenyl iodide $\mathbf{8}$ and carbocation 9. The sulfenyl iodide 8 can then undergo nucleophilic addition of iodine to regenerate iodine catalyst and produce thiolate 10 . The carbocation 9 can react with electron rich arene 2, followed by hydrogen atom abstraction mediated by thiolate, furnishing the desired FC products 3 and thiol 11. On the other hand, when tritylium tetrafluoroborate $\mathbf{4 c}$ is added in the reaction, the cation may activate the iodosulfonium ion through a possible Lewis acid assisted Lewis acid model 12, thus facilitating the cleavage of C-S bond. Then, based on Yoshida's work, ${ }^{14}$ the triphenylmethylium thiolate $\mathbf{1 3}$ generated during this step can be in equilibrium with thiolate $\mathbf{1 0}$ and tritylium tetrafluoroborate $\mathbf{4 c}$, and thus allowing the regeneration of cocatalyst. It is also conceivable that electrophilic sulfonium ion $\mathbf{1 2}$ may directly act as a Lewis acid to promote the formation of carbocation 9.

The observation of characteristic odor of thiol at the end of the reaction in both catalytic conditions seems to support our proposed catalytic cycle. ${ }^{15}$ In addition, results from table 1 ( entries 16 to 19) definitively established that the nature of the cation plays an important role in the reaction Nevertheless, at the present stage, we cannot exclude the pathway involving Brønsted acid catalysis $\left(\mathrm{HBF}_{4}\right)$. However, when $\mathrm{HBF}_{4} \cdot \mathrm{OEt}_{2}$ was used instead of $\mathbf{4 c}$, the triarylated product was isolated in lower yield ( $C$, Scheme 3 ). For the control experiment, in absence of iodine, lower amount of product 3a was found. This supports the possibility of Lewis-acid assisted iodine catalysis.

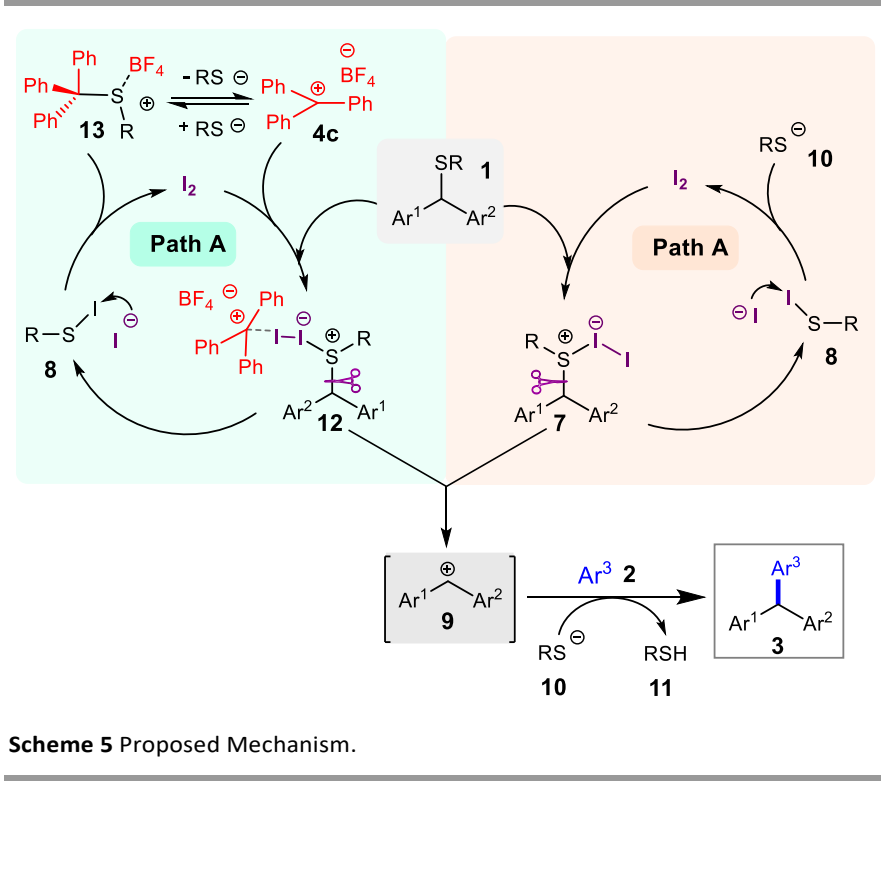

\section{Conclusions}

In summary, we have developed an efficient synthesis of unsymmetrical triarylmethanes using a Lewis acid assisted Lewis acid catalyst system under mild conditions. We have demonstrated that iodine in the presence of catalytic amount of trityl cation was efficient catalyst for the FC arylation of diarylmethyl sulfides. This novel catalytic protocol provides a 
simple and efficient entry to unsymmetrical triarylmethanes in high yields. The substitution patterns readily achievable by this Lewis acid-assisted-Lewis acid approach complement our previous photocatalyzed method. ${ }^{5 a}$

\section{Conflicts of interest}

There are no conflicts to declare.

\section{Acknowledgements}

We gratefully acknowledge CNRS, ICSN for financial support. M.L. thanks ICSN for a doctoral fellowship. T.C. thanks the CNRS for postdoctoral fellowships, M.L. thanks Saclay University for the doctoral fellowships and D. V. B. thanks Labex Charm3at for a financial support of Master.

\section{Notes and references}

1 For reviews on the synthesis of triarylmethanes, see: (a) Q. Yang, R.-S. Wu, K.-X. Wu, Y.-C. Gu, Y.-Q. Yu and D.-Z. Xu, Appl Organomet Chem. 2020, 34, doi: 10.1002/aoc.5716; (b) R. Kshatriya, V. P. Jejurkar and S. Saha, Eur. J. Org. Chem. 2019, 3818-3841; (c) S. Mondal, A. Verma and S. Saha, Eur. J. Org. Chem. 2019, 864-894; (d) S. Mondal and G. Panda, RSC Adv. 2014, 4, 28317-28358; (e) V. Nair, S. Thomas, S. C. Mathew and K. G. Abhilash, Tetrahedron 2006, 62, 6731-6747; (f) M. S. Shchepinov and V. A. Korshun, Chem. Soc. Rev. 2003, 32, 170-180; (g) D. F. Duxbury, Chem. Rev. 1993, 93, 381-433. Selected examples of biologically active natural and nonnatural triarylmethanes: (h) D. F. Dibwe, S. Awale, S. Kadota, H. Morita and Y. Tezuka, J. Nat. Prod. 2014, 77, 1241-1244; (i) M. K. Parai, G. Panda, V. Chaturvedi, Y. K. Manju and S. Sinha, Bioorg. Med. Chem. Lett. 2008, 18, 289-292; (j) A. K. S. Shagufta; R. Sharma, R. Mishra, A. K. Balapure, P. S. R. Murthy and G. Panda, Bioorg. Med. Chem. 2006, 14, 14971505; (k) N. Mibu, K. Yokomizo, M. Uyeda, and K. Sumoto Chem. Pharm. Bull. 2005, 53, 1171, (I) O. Seligmann and H. Wagner, Tetrahedron 1981, 37, 2601-2606.

2 For a recent review, see: (a) J. E. Taylor and S. EstopiñáDurán, Chem. Eur. J. 2020, 26, doi:10.1002/chem.202002106; Selected examples: (b) M. Böldl and I. Fleischer, Eur. J. Org. Chem. 2019, 5856-5861; (c) I. Jesin C. P., A. A. H. Mercy, R. S., R. Kataria, G. C. Nandi, J. Org. Chem. 2020, 85, 30003009; (d) Y.-C. Gu, J. Huang, R.-S. Wu, Q. Yang, Y.-Q. Yu and D.-Z. Xu New J. Chem. 2020, 44, 5519-5525; (e) H. T. Ang, J. P. G. Rygus and D. G. Hall, Org. Biomol. Chem. 2019, 17, 6007-6014; (e) L. Yu, S.-S. Li, W. Li, S. Yu, Q. Liu and J. Xiao, J. Org. Chem. 2018, 83, 15277-15283; (f) N. Suzuki and K. Nakata, Eur. J. Org. Chem. 2017, 7075-7086; $(g)$ G. Pallikonda and M. Chakravarty, J. Org. Chem. 2016, 81, 2135-2142; (h) S. Ruengsangtongkul, P. Taprasert, U. Sirion and J. Jaratjaroonphong, Org. Biomol. Chem. 2016, 14, 84938502; (i) G. Pallikonda and M. Chakravarty, J. Org. Chem. 2016, 81, 2135-2142; (j) M. Nambo, Z. T. Ariki, D. C. Gonzalez and D. D. Beattie, Org. Lett. 2016, 18, 2339-2342; (k) R. F. A. Gomes, J. A. S. Coelho, R. F. M. Frade, A. F. Trindade and C. A. M. Afonso, J. Org. Chem. 2015, 80, 10404-10411; (I) Y. Li, Y. Xiong, X. Li, X. Ling, R. Huang, X. Zhang, J. Yang, Green Chem. 2014, 16, 2976-298; (m) P. Thirupathi, S. S. Kim, J. Org. Chem. 2010, 75, 5240-5249; (n)
Y. Sato, T. Aoyama, T. Takido and M. Kodomari, Tetrahedron 2012, 68, 7077-7081; (o) P. Shukla, M. K. Choudhary and S. K. Nayak, Synlett 2011, 11, 1585-1591; (p) G. K. Prakash, C. Panja, A. Shakhmin, E. Shah, T. Mathew and G. A. Olah, J. Org. Chem. 2009, 74, 8659-8668; (q) J. Jaratjaroonphong, S. Sathalalai, P. Techasauvapak and V. Reutrakul, Tetrahedron Lett. 2009, 50, 6012-6015; (r) Y. Yamamoto and K. Itonaga, Chem. Eur. J. 2008, 14, 10705-10715; (s) Y. Liu, S. Zhou, G. Li, B Yan, S. Guo, Y. Zhou, H. Zhang, P. G. Wang, Adv. Synth. Catal. 2008, 350, 797-801. (t) J. Esquivias, R. Gomez Arrayás and J. C. Carretero, Angew. Chem. Int. Ed. 2006, 45, 629-633; (u) R. M. Roberts, A. M. El-Khawaga, K. M. Sweeney and M. F. El-Zohry, J. Org. Chem. 1987, 52, 1591-1599; (v) A. Burmester and H. B. Stegmann, Synthesis 1981, 2, 124-125; See also, (w) L. Yu, S.-S. Li, W. Li, S. Yu, Q. Liu and J. Xiao, J. Org. Chem. 2018, 83, 15277-15283. For selected enantioselective versions, see: $(x)$ C. Yue, F. Na, X. Fang, Y. Cao and J. C. Antilla, Angew. Chem. Int. Ed. 2018, 57, 1100411008; (y) C.-C. Hsiao, H.-H. Liao and M. Rueping, Angew. Chem. Int. Ed. 2014, 53, 13258-13263. (z) O. El-Sepelgy, S. Haseloff, S. K. Alamsetti and C. Schneider, Angew. Chem. Int. Ed. 2014, 53, 7923-7927. (aa) T. Nokami, Y. Yamane, S. Oshitani, J.-k. Kobayashi, S.-i. Matsui, T. Nishihara, H. Uno, S. Hayase and T. Itoh, Org. Lett. 2015, 17, 3182-3185. (ab) H. Yu, R. Lee, H. Kim, D. Lee, J. Org. Chem. 2019, 84, 3566-3578.

3 For a recent review using other methods, see: (a) M. Nambo and C. M. Crudden, ACS Catal. 2015, 5, 4734-4742; For recent examples, see: (b) Z. Zhang, H. Wang, N. Qiu, Y. Kong, W. Zeng, Y. Zhang, J. Zhao, J. Org. Chem. 2018, 83, 8710-8715; (c) J. H. Kim, S. Greßies, M. Boultadakis-Arapinis, C. Daniliuc and F. Glorius, ACS Catal. 2016, 6, 7652-7656; (d) S. C. Matthew, B. W. Glasspoole, P. Eisenberger and C. M. Crudden, J. Am. Chem. Soc. 2014, 136, 5828-5831; (e) M. Nambo, E. C. Keske, J. P. G. Rygus, J. C.-H. Yim and C. M. Crudden, ACS Catal. 2017, 7, 1108-1112; (f) J.-Y. Liao, Q. Ni, Y. Zhao, Org. Lett. 2017, 19, 4074-4077; (g) Y. Xia, L. C., P. Qu, G. Ji, S. Feng, Q. Xiao, Y. Zhang and J. Wang, J. Org. Chem. 2016, 81, 10484-10490; (h) S. Guduguntla, J.-B. Gualtierotti, S. S. Goh, B. L. Feringa, ACS Catal. 2016, 6, 6591-6595; (i) M. Nambo, Z. T. Ariki, D. Canseco-Gonzalez, D. D. Beattie and C. M. Crudden, Org. Lett. 2016, 18, 2339-2342; (j) P. Arde and R. V. Anand, RSC Adv. 2016, 6, 77111-77115.

4 For simple syntheses of diarylmethyl sulfides, see: (a) R. Parnes and D. Pappo, Org. Lett. 2015, 17, 2924-2927 and references inside; (b) C. Miao, H. Zhuang, Y. Wen, F. Han, Q.F. Yang, L. Yang, Z. Li and C Xia Eur. J. Org. Chem. 2019, 2019, 3012-3021; (c) G. Frensch, N. Hussain, F. A. Marques and Patrick J. Walsh, Adv. Synth. Catal. 2014, 356, 2517-2524.

5 (a) M. Lanzi, J. Merad, D. Boyarskaya, G. Maestri, C. Allain and G. Masson, Org. Lett. 2018, 20, 5247-5250; See also: (b) L. Jarrige, A. Carboni, G. Dagousset, G. Levitre, E. Magnier and G. Masson, Org. Lett. 2016, 18, 2906-2909; (c) C. Lebée, M. Languet, C. Allain and G. Masson, Org. Lett. 2016, 18, 14781481; (d) T. Le, T. Courant, J. Merad, C. Allain, P. Audebert and G. Masson. J. Org. Chem. 2019, 84, 16139-16146; (e) G. Levitre, C. Audubert, A. Dumoulin, N. Goual, P. Retailleau, X. Moreau and G. Masson, ChemCatChem 2019, 11, 5723-5727.

6 Photocatalyzed C-S bond cleavage of thioglycosides: (a) M. L. Spell, K. Deveaux, C. G. Bresnahan, B. L. Bernard, W. Sheffield, R. Kumar and J. R. Ragains, Angew. Chem. Int. Ed. 2016, 55, 6515-6519; (b) W. J. Wever, M. A. Cinelli and A. A. Bowers, Org. Lett. 2013, 15, 30-33.

7 For selected examples of C-S bond cleavage, see: (a) K. Yang, Y. Li, Z. Ma, L. Tang, Y. Yin, H. Zhang, Z. Li and X. Sun Eur. J. Org. Chem. 2019, 5812-5814; (b) H. Minami, K. Nogi and H. Yorimitsu, Org. Lett. 2019, 21, 2518-2522; (c) Y. Ma, J. Cammarata and J. Cornella, J. Am. Chem. Soc. 2019, 141, 1918-1922; (d) H. Minami, S. Otsuka, K. Nogi and H. Yorimitsu, 
ACS Catal. 2018, 8, 579-583; (e) Z. Lian, B. N. Bhawal, P. Yu and B. Morandi, Science 2017, 356, 1059-1063; (f) T. Shibata, A. Mitake, Y. Akiyama and K. S. Kanyiva, Chem. Comm. 2017, 53, 9016-9019; $(g)$ I. Burkhardt, L. Lauterbach, N. L. Brock and J. S. Dickschat, Org. Biomol. Chem. 2017, 15, 4432-4439; (h) D. Canestrari, S. Lancianesi, E. Badiola, C. Strinna, H. Ibrahim and M. F. A. Adamo, Org. Lett. 2017, 19, 918-921; (i) M. Iwasaki, N. Topolovčan, H. Hu, Y. G. Nishimura, Y. G. Gagnot, R. Nanakorn, R. Yuvacharaskul, K. Nakajima and Y. Nishihara, Org. Lett. 2016, 18, 1642-1645; (j) Y. Uetake, T. Niwa and T. Hosoya, Org. Lett. 2016, 18, 2758-2761; (k) K. Gao, H. Yorimitsu and A. Osuka, Angew. Chem. Int. Ed. 2016, 55 4573-4576; (I) N. George, M. Bekkaye, A. Alix, J. Zhu and G. Masson, Chem. Eur. J. 2014, 20, 3621-3625; (m) T. Sugahara, K. Murakami, H. Yorimitsu and A. Osuka, Angew. Chem. Int Ed. 2014, 53, 9329-9333; (n) N. George, M. Bekkaye, G. Masson and J. Zhu, Eur. J. Org. Chem. 2011, 2011, 3695-3699.

8 For reviews, see: (a) M. S. Yusubov and V. V. Zhdankin, Resour.-Effic. Technol. 2015, 1, 49-67; (b) Y. M. Ren, C. Cai and R. C. Yang, RSC Adv. 2013, 3, 7182-7204; (c) H. Togo and S. lida, Synlett 2006, 14, 2159-2175. For selected reactions mediated by iodine, see: (d) A. K. Pandey, S. Chand, R. Singh, S. Kumar and K. N. Singh ACS Omega 2020, 5, 7627-7635; (e) P. Bhattacharjee and U. Bora, ACS Omega 2019, 4, 1177011776; (f) K .Čebular and S. Stavber, Pure Appl. Chem. 2018 90, 377-386; (g) M. Breugst and D. von der Heiden, Chem. Eur. J. 2018, 24, 9187-9199; (h) D. von der Heiden, S. Bozkus, M. Klussmann and M. Breugst, J. Org. Chem. 2017, 82, 40374043; (i) S. Yi, M. Li; W. Mo, X. Hu, B. Hu, N. Sun, L. Jin and Z. Shen, Tetrahedron Lett. 2016, 57, 1912-1916; (j) H. Qi, T. Zhang, K. Wan and M. Luo, J. Org. Chem. 2016, 81, 4262-4268; (k) H. Y. Huang, H. R. Wu, F. Wei, D. Wang and L. Liu, Org. Lett. 2015, 17, 3702-3705; (I) S. Tang, K. Liu, Y. Long, X. Gao, M. Gao and A. Lei, Org. Lett. 2015, 17, 2404-2407; (m) S. K. R. Parumala and R. K. Peddinti, Green Chem. 2015, 17, 40684072; (n) T. H. Zhu, S. Y. Wang, Y. Q. Tao and S. Ji, J. Org. Lett 2015, 17, 1974-1977; (o) F. Xiao, H. Chen, H. Xie, S. Chen, L. Yang and G.-J. Deng, Org. Lett. 2014, 16, 50-53; ( $p$ ) Q. Gao, X. Wu, S. Liu and A. Wu, Org. Lett. 2014, 16, 1732-1735; (q) Q. Gao, X. Wu, Y. Li, S. Liu, X. Meng and A. Wu, Adv. Synth. Catal. 2014, 356, 2924-2930; (r) F. L. Yang, F. X. Wang, T.T. Wang, Y. J. Wang and S. K. Tian, Chem. Commun. 2014, 50, 2111-2113 (s) A. Ilangovan and G. Satish, J. Org. Chem. 2014, 79, 49844991; (t) W. Ge, X. Zhu and Y. Wei, Adv. Synth. Catal. 2013, 355, 3014-3021; (u) M. Jereb and D. Vražičb, Org. Biomol. Chem. 2013, 11, 1978-1999; (v) J. Jaratjaroonphong, S. Krajangsri and V. Reutrakul, Tetrahedron Lett. 2012, 53, 2476 2479.

9 For selected reviews, see: (a) M. M. Nielsen and C. M. Pedersen, Chem. Rev. 2018, 118, 8285-8358; (b) C. S. Bennett and M. C. Galan, Chem. Rev. 2018, 118, 7931-7985; (c) R. Das and B. Mukhopadhyay, ChemistryOpen 2016, 5, 401-433; (d) J. D. C. Codée, R. E. J. N. Litjens, L. J. van den Bos, H. S. Overkleeft and G. A. van der Marel, Chem. Soc. Rev. 2005, 34, 769-782; The first examples: (e) P. Cura, M. Aloui, K. P. R. Kartha and R. A. Field, Synlett 2000, 9, 1279-1280; (f) K. P. R. Kartha, P. Cura, M. Aloui, S. K. Readman, T. J. Rutherford and R. A. Field, Tetrahedron: Asymmetry 2000, 11, 581-593; (g) P. Konradsson, U. E. Udodong and B. Fraser-Reid, Tetrahedron Lett. 1990, 31, 4313-4316; (h) G. H. Veeneman, S. H. van Leeuwen and J. H. van Boom. Tetrahedron Lett. 1990, 31 1331-1334; (i) H. M. Zuurmond, S. C. Van der Laan, G. A. Van der Marel and J. H. Van Boom, Carbohydr. Res. 1991, 215, C1.

10 For a review, see: (a) H. Yamamoto and K. Futatsugi, Angew. Chem. Int. Ed. 2005, 44, 1924-1943; Selected examples: (b) K. Futatsugi, H. Yamamoto, Angew. Chem. Int. Ed. 2005, 44 1484-1487; (c) G. Xia, K. Shibatomi and H. Yamamoto, Synlett
2004, 2437-2439; (d) M. Oishi, S. Aratake, H. Yamamoto, J. Am. Chem. Soc. 1998, 120, 8271-8272.

11 For selected examples combining iodine catalyst with Lewis or Brønsted acid catalyst, see: (a) W. Fu, L. Dong, J. Shi, B. Tong, Z. Cai, J. Zhi and Y. Dong Polym. Chem. 2018, 9, 4404-4412; (b) S.-K. Chung and K. H. Park, Tetrahedron Lett. 2001, 42, 4005-4007. See also: (c) T. Hashihayata, K. Ikegai, K. Takeuchi, H. Jona and T. Mukaiyama, Bull. Chem. Soc. Jpn. 2003, 76, 1829-1848; (d) P. Konradsson, D. R. Mootoo, R. E. McDevitt and B. Fraser-Reid, J. Chem. Soc. Chem. Commun. 1990, 270272; See also ref 8.

12 For reviews of carbocation Lewis acid catalysis, see: (a) V. R. Naidu and S. Ni J. Franzén, ChemCatChem 2015, 7, 18961905; (b) R. R. Naredla and D. A. Klumpp, Chem. Rev. 2013, 113, 6905-6948; (c) O. Serada, S. Tabassum and R. Wilhelm, Top Curr. Chem. 2010, 291, 349-393; For selected examples of carbocation Lewis acid catalysis, see: (d) H. Jin, M. Rudolph, F. Rominger and A. S. K. Hashmi, ACS Catalysis 2019, 9, 1166311668; (e) Q. Zhang, J. Lv and S. Luo, Beilstein J. Org. Chem. 2019, 15, 1304-1312; (f) W. Shang, D. Duan, Y. Liu, J. Lv, Org. Lett. 2018, 21, 8013-8017; $(\mathrm{g}) \mathrm{S}$. Ni and J. Franzén, Chem. Comm. 2018, 54, 12982-12985; (h) S. Ni, M. A. E. Aleem, A. A. El Remaily and J. Franzén, Adv. Synth. Catal 2018, 360, 41974204; (i) Q. Zhang, J. Lv, S. Li and S. Luo Org. Lett. 2018, 20 2269-2272; (j) W. Zhu, Q. Sun, Y. Wang, D. Yuan and Y. Yao, Org. Lett. 2018, 20, 3101-3104; (k) D. J. M. Lyons, R. D. Crocker, D. Enders and T. V. Nguyen, Green Chem. 2017, 19, 3993-3996; (I) J. Liu, J. Xu, Z. Li, Y. Huang, H. Wang, Y. Gao, T. Guo, P. Ouyang and K. Guo, Eur. J. Org. Chem. 2017, 39964003; $(m)$ E. Mosaferi, D. Ripsman and D. W. Stephan, Chem. Commun. 2016, 52, 8291-8293; (n) J. Bah, V. R. Naidu, J. Teske and J. Franzén, Adv. Synth. Catal. 2015, 357, 148-158; (o) M. A. E. A. A. A. El Remaily, V. R. Naidu and S. Ni, J. Franzén, Eur. J. Org. Chem. 2015, 6610-6614; (p) J. Bah and J. Franzén, Chem. Eur. J. 2014, 20, 1066-1072; (q) S. Taudien, O. Riant and H. B. Kagan, Tetrahedron Lett. 1995, 36, 3513-3516; $(r)$ T. Mukaiyama, H. Akamatsu and J. S. Han, Chem. Lett. 1990, 889; (s) S. Kobayashi, S. Matsui, T. Mukaiyama, Chem. Lett. 1988, 1491; (t) M. Oshima, M. Murakami and T. Mukaiyama, Chem. Lett. 1985, 1871; (u) T. Mukaiyama, S. Kobayashi and M. Murakami, Chem. Lett. 1985, 447; (v) T. Mukaiyama, S. Kobayashi and M. Murakami, Chem. Lett. 1984, 1759.

13 For related stoichiometric copper promoted transformation see: T. Mukaiyama, K. Narasaka, K. Maekawa and H. Hokonoki, Bull. Chem. Soc 1970, 43, 2549-2553; For Lewis acid intramolecular mono displacement, see: R. Singh and G. Panda, Org. Biomol. Chem. 2010, 8, 1097-1105; J. D. Leber and J. D. Elliot, Tetrahedron Lett. 1989, 30, 6849-6850.

14 Y. Kim, K. Kanemoto, K. Shimomori, T. Hosoya and S. Yoshida, Chem. Eur. J. 2020, 26, 6136-6140.

15 Analysis of the $1 \mathrm{H}$ NMR of the reaction after $8 \mathrm{~h}$ shows the formation of BnSH 11a (see, in Supporting Information). 